\title{
Legal Protection of Pre-school Children's Right to Education
}

\author{
Jing Zhang ${ }^{1}$, Liyun Lu ${ }^{2}$ \\ ${ }^{1}$ School of Public Affair and Law, Southwest Jiaotong University, Chengdu, Sichuan 610031, China; \\ ${ }^{2}$ School of Public Affair and Law, Southwest Jiaotong University, Chengdu, Sichuan 610031, China.
}

Keywords: Preschool Children; Right to Education; Reason; Legal protection.

\begin{abstract}
Pre-school children's right of getting education is one of the basic human rights legally guaranteed by the constitution and plays an essential role for achieving successful child development as well. To comprehensively protect children's right to education, this article focuses on the problems of legal protection of pre-school children's right to education and deeply analyzes the causations and provides suggestions through five different aspects, such as revising legislation, increasing financial investments, improving administrative institution or educational appeal department, and establishing legal constitution lawsuit system.

Pre-school children's right to education is the basic right of pre-school children stated by the constitution and the indispensable right for children to grow up well. The article in the "Constitution of the People's Republic of China" (2018) assigns the right of pre-school children to receive education; however, the guarantee from the constitution does not equal to solid possessions of such education rights to pre-school children. The administrative activities and judicial succors are indeed. Despite the success in our nation has about the preschool children's right to education, we are still facing serious issues and challenges. To solve the problems and protect the children's right to education is the priority goals to achieve right now.
\end{abstract}

\section{Overview of The Pre-school Children's Rights to Education}

\subsection{The definition of pre-school children}

According to the "UN convention on the Rights of the Child," "A child is defined as every human being that below the age of eighteen years unless under the law applicable to the child and majority is attained earlier." (CRC 2) The "Law of the People's Republic of China on the Protection of Minors" (2012) in China follows the international rule, which defines citizens under the age of eighteen as minors. Moreover, the "Working Rules for Kindergartens" (2016) states pre-school children are children from three to six years old.

\subsection{The intention and characterization of rights to education}

The right to education not only refers to the opportunities a nation provides to citizens about access to education but also the right to obtain education-related physical assistances [1]. Article 46 in the “Constitution of the People's Republic of China” states, "Citizens of the People's Republic of China have the duty as well as the right to receive education. The state promotes the all-round development of children and young people, morally, intellectually and physically.” As all we can see, right to education is one of the basic human rights ensured and guaranteed by legislation. The right to education contains two characteristics of rights of which the citizen's freedom and fundamental social rights, is a composite prosperity human right [2]. The citizens' freedom in the right to education ensures citizens' free choices about the method and content of their education. The nation does not have the right to interfere their rights. Moreover, the characteristic of fundamental social right in right to education stipulates the nation's obligation of building up required environment and offering necessary supplies for the citizens gaining their right to education successfully.

\subsection{The right to education of pre-school children}

On one hand, children's right to education is the right for kids to study the mostly through games in kindergarten or any other educational institutions. Pre-school children may absorb some scientific knowledge during the process of playing or gaming. But learning those knowledge is not the priority contents for them. In fact, this concept will meet the physical and mental features of child-development. On the other hand, the right to education of pre-school children is a right needs our nation to provide assuredly. Government and related 
social institutions should take their responsibility actively to achieve the right to education of pre-school children.

\section{The Current Situations of Legal Protection for Children's Right to Education in China}

From the national perspective, the legal protection for children's right to education can be applied from three aspects, legislation, administration and judiciary. Specifically, government can protect pre-school children's right to education by putting legislations into effect, improving administrative supplies, activating judicial succor and other legal system, legal practice or legal procedure. Nowadays, even though the government is putting more efforts on the issue of protecting children's right to education, the lack of legislation protection, administrative activity and judicial succor is still the inevitable problems.

\subsection{The lack of legislation protection}

Even though our government have a few laws related with children's right to education, the legislations that secure the children's right to education is still insufficient right now. Within all the preschool education legislations, "Education Law of the People's Republic of China" and "Regulations on the Management of Kindergartens" is the only two legislations involve laws related with children right to education. Besides, in the present laws, pre-school education has not been included into the compulsory education category assigned by "Compulsory Education Law of the People's Republic of China"; therefore, there is no consolidate law in the field to provide evidence, the children's right to education is not hundred percent guaranteed [3]. The fact that preschool education is not part of the compulsory education causes the government supervisors pay less attention with preschools. In this case, the quality of education between different kindergartens can be various; the tuition of great preschools is unaffordable. Thus, some preschool children are not able to obtain appropriate preschool education because of the low quality of their preschools, other children may not able to pay the high tuition then lose their chance to receive preschool education. All in all, the lack of legislation protection is the cause of all those tragedies.

\subsection{The lack of administrative activity}

Although preschool education had been improved a lot after the "Early Childhood Education Three-Year Action Plan" started, there is still some deficiencies along with the administration aspect.

First, the effective administrations of preschool education from the government are not enough. Our preschool education administration system is falling back, which basically reveals by the unsent of a general department which can take control of the entire system. Nowadays, the district government systems are the ones who have the authority of managing the preschool education along with the constitution articles. In reality, those government systems do not establish a specific administration department which can take control of supervising preschool education. Without the appearance of an independent leader or a reliable supervision institution, the responsibility between preschool education related departments is unclear, and the cooperation work is indeterminate, which cause the failure of supervision and further against the protection of preschool children's right to education.

Second, the lack of public kindergartens and the poor administrations of the private kindergartens is a huge problem. The combination of public and private kindergartens, dominating by private kindergartens is the preschool education method our nation had been following. Nevertheless, when a lot of private kindergartens renew their system, the number of public kindergartens is decreasing. According to the data, only 35.7 percent out of 239.8 thousand kindergartens in 2016 is public school [4]. This data clearly shows that public kindergartens are less than private kindergartens; it is a small proportion of preschools. In order to fulfill the need of preschools, a massive number of private preschools appear. Nonetheless, the administrative management and standardization of the examination for the private preschool's qualification, the payment standardization, requirements of kindergarten's establishing, and competency of preschool teachers are not yet published. Therefore, the undesirable situations such as various qualities between private preschools, the extremely high tuitions and uncertified teachers always appear. In conclusion, the limited amount of public kindergarten, large number of unqualified private kindergartens, the lack of administration institutions are the major issues affects the right to education of preschool children. 


\subsection{The imperfection of the way of judicial aids}

Civil procedure, administration appeal and administration procedure are the main ways the government use to solve education related dissensions. Through concrete practice, however, it is found that these approaches have limitations in protecting preschool children's rights to education.

First of all, when it comes to the exercise of public authorities, such as the state infringes upon the rights to education of pre-school children by using public authorities, often cannot be solved simply by civil litigation. Secondly, the "Education Law of the People’s Republic of China” does not clarify the specific process and time limit for administration appeal about preschool children's right to education. Last, due to the fact that preschool education does not count as compulsory education, there is no education administration relationship between kindergartens and preschool children. Thus, kindergartens are not the proper defendant of administration procedure. Moreover, "The Administrative Litigation Law of the People's Republic of China” does not have any specific rules for these circumstances.

\section{Causes of The Law Deficiency about Children’s Right to Education Protection Analysis}

\subsection{The absence of a "preschool education law of the People's Republic of China”}

In our nation, the "Education Law of the People's Republic of China" stipulates a school education system embracing preschool education, primary education, secondary education and higher education. At the same time, the state also issues the nine-year compulsory education system, a system of vocational education and a system of adult education. For the purpose, the government publishes the "Compulsory Education Law of the People's Republic of China", the "Vocational Education Law of the People's Republic of China," the "Higher Education Law of the People's Republic of China," and other slip laws. The nine-year compulsory education system covers the primary and secondary education but does not guarantee preschool education. The deficiency of a preschool education law leads to the lack of law facts while try to protect the right to education of preschool children and construct a prefect protection law system for rights to education.

\subsection{The lack of financial investment in the preschool education field}

The 53 articles in the "Education Law of the People’s Republic of China” states, “The State practices a system wherein government appropriations constitute the main body of the educational appropriations, supplemented by funds raised from a variety of other sources, and the State gradually increases its educational input as so to ensure a stable source of educational appropriations for State-run schools.” As the articles say, right to education is basic human rights given by the constitution and government is primary obligatory subject of the right to education. Even though the government put some funds into preschool education and somehow protect the right to education, that money only take over a low percentage in the total education funds. Because they can only receive a small amount investment from government, kindergartens have to enlarge class scales, increase tuition and use other ways to maintain operating. This is one of the reasons why kindergartens illegally take in too many students and have low education quality.

\subsection{The lack of constitution litigation system}

Generally, judicial authorities are jurally required to illustrate the related lawsuits when the basic rights have not crystalized by lawgivers in order to perform the protective duty with citizens' fundamental rights [5]. When preschool children do not gain their rights to education completely or other succor is not available, they should be able to conducting prosecutions along with constitution. Nonetheless, according to the constitution's applicability and explanations we have today, the possibility of court quoting constitution on realistic ad judgment is still contentious. Due to the fact that constitution is not perfect when carry out into reality, preschool children sometimes are unable to received feasible guarantees after their rights had been invaded if they try to find judicial succor. Briefly, situations like preschool children's right to education got invaded but not able to receive any supplies happen during the process of finding help because of the imperfect constitution litigation system. 


\section{The Effective Paths to Protect Preschool Children's Right to Education}

In order to deal with the existing problems of preschool children's right to education in China, we can draw lessons from foreign countries and learn from their method or system. Thus, five solutions would be listed to solve these problems so then we can protect pre-school children's right to education comprehensively.

\subsection{Perfecting the legislation of preschool children's right to education}

"Preschool Education Law of the People’s Republic of China” was formulated and published. The current problems in China's preschool education largely stem from the lack of laws specifically regulating preschool education. The legislature needs to concretize the guarantee of preschool children's right to education so that the administrative department and the judicial department can directly apply it. We should pay attention to the following aspects when we formulate Preschool Education Law of the People's Republic of China. First, clarify the status of preschool education, and emphasize its untrue of publicity and public welfare. Second, the funding system of pre-school education should be improved to ensure the funding source of pre-school education. Third, we should formulate preferential policies to protect the education rights of vulnerable children, including those who are economically poor, disabled, ethnic minorities, left behind in rural areas and among urban migrants. What's more, the status, qualifications, responsibilities and benefits of preschool education practitioners should also be clarified.

\subsection{Increasing the government investment and establishing tuition sharing mode}

Local governments at all levels must pay attention to preschool children's right to education, and list preschool education funds separately in financial budget. Also, government should improve the proportion of preschool education funds in total educational expenditure and supervise how to use it. Besides, establish a proper tuition sharing mode. On the one hand, government should play a leading role in the economic input of preschool education. That is to say, the government should pay the main cost of preschool education for children. On the other hand, families should also take responsibility for their children and bear part of the educational expenses. However, we should take different countermeasures according to the financial condition of different regions and the economic condition of different families. Moreover, the central government should increase financial support for preschool education in poverty-stricken areas and narrow the economic gap.

\subsection{Improving preschool education administration system}

According to the actual situation of our country, state organs can establish and improve preschool education administration system. For example, local governments at all levels set up independent institutions and hire professional personnel to handling relevant affairs, which can improve the efficiency evidently. Besides, enhancing supervision of the private kindergartens and strictly approved their quality. Moreover, examining preschool teachers' qualification and teaching quality regularly so that we can ensure the right to education of pre-school children.

\subsection{Improving educational appeal system}

Article 42 in the "Education Law of the People's Republic of China" states, "Educatees shall enjoy the following rights: ...to lodge a complaint with the competent department if he or she refuses to accept punishment imposed by the school, and lodge a complaint or bring a lawsuit, in accordance with law, against an infringement upon his or her right of the person or property or other lawful rights and interests by the school authorities or teachers." So, pre-school children also have the right to apply for educational appeal. Educational appeal system needs improving in the way of the appeal organization, the appeal process, and the relief channel after the educational appeal.

\subsection{Establishing the system of constitutional litigation}

The system of constitutional litigation is the most essential part of the Constitution. Establishing the system of constitutional litigation is the inevitable choice to realize constitutionalism and build a country under the rule of law. Also, it plays an important role in confirming the authority of the constitution, promoting democracy and protecting the basic rights of citizens. Basically, as a constitutional right, pre-school children's right to education should be relieved by constitutional litigation. Therefore, the government agencies should strengthen the interpretation of the constitution articles and explain them definitely, which 
can be invoked by judges in judicial practice. Constitutional litigation system is established to protect pre-school children's right to education while they are violated and cannot be effectively relieved by other measures. Constitutional relief can be the last but most effective way to protect rights so as to protect preschool children's right to education perfectly.

\section{Conclusion}

In recent years, our country has been paying more and more attention to the protection of preschool children's right to education, but there are still some shortcomings. Only by overcoming the existing problems and promoting the balanced development of pre-school education can we distribute reasonably education resources. So that we can achieve educational equity and guarantee human rights better. This requires the government to further improve the legal protection mechanism of preschool children's right to education from the legislative, administrative and judicial aspects. Only by the joint efforts of the three parties can we effectively guarantee the right of preschool children and improve as well as develop the education in china.

\section{Acknowledgment}

This work is supported by the Ministry of Education under the project "Legal Protection of Pre-school Children's Right to Education”(1 8YJCZH235) and“ the Fundamental Research Funds for the Central Universities" under the project "The realistic factors that affect the judicial identification of the public and its countermeasures”.

\section{References}

[1]. Cai Ding-jian. “The Solve Precisely of Constitution,” [M]. Law Press-China, 2006, 277.(In Chinese)

[2]. Wen Hui, “On Educational Right into the Constitution,” [M]. Peking University Press, 2003, 103. (In Chinese)

[3]. Ruan Ling-yan. "Protection of Children's Right to Education in China,” [J]. Legality Vision, 2015(11), 238. (In Chinese)

[4]. Nie Shuai-jun. “Improvement of Legal Protection Mechanism for Preschool Children's Right to Education in China,” [J]. Hebei Law Science, 2018(8), 149. (In Chinese)

[5]. Chen Zheng. "Constitutional Boundary between State Power and Civil Rights,” [M]. Tsinghua University Press, 2015, 54. (In Chinese) 